\title{
Analisis Model Pembelajaran SQ3R Dalam Meningkatkan Membaca Pemahaman Siswa SD
}

\author{
Dwi Hilana Yesika \\ Pendidikan Guru Sekolah Dasar - Universitas Muhammadiyah Surabaya \\ dwi.hilana.yesika-2018@fkip.um-surabaya.ac.id \\ Fitroh Setyo Putro Pribowo \\ Pendidikan Guru Sekolah Dasar - Universitas Muhammadiyah Surabaya \\ fitrohsetyo@fkip.um-surabaya.ac.id \\ Kunti Dian Ayu Afiani \\ Pendidikan Guru Sekolah Dasar - Universitas Muhammadiyah Surabaya \\ kuntidianayu@fkip.um-surabaya.ac.id
}

\begin{abstract}
Abstrak
Penelitian ini bertujuan untuk menganalisis penggunaan model pembelajaran Survey, Question, Read, Recite, Review (SQ3R) guna meningkatan membaca pemahaman siswa. Jenis penelitian ini yaitu penelitian kualitatif dengan menggunakan metode meta analisis. Penelitian ini diawali dengan merumuskan masalah penelitian, mencari data atau jurnal yang relevan untuk dilakukan analisis. Dari penelusuran diperoleh hasil data penelitian 10 artikel yang relevan. Yaitu 8 artikel Penelitian Tindakan Kelas (PTK) dan 2 artikel kuantitatif (eksperimen). Pada Penelitian Tindakan Kelas (PTK) diperoleh hasil rata-rata ketuntasan hasil belajar sebesar $87,71 \%$. Sedangkan pada penelitian kuantitatif (eksperimen) didapatkan hasil bahwa SQ3R berpengaruh terhadap membaca pemahaman siswa dibuktikan dengan hasil uji t kedua penelitian dengan skor $t^{1}=2,212$, $t^{2}=6,29$ dengan diperoleh rata-rata 4,251 sehingga disimpulkan bahwa nilai t hitung > $t$ tabel. Jadi dapat disimpulkan pemakaian model pembelajaran $S Q 3 R$ berhasil meningkatkan belajar siswa.
\end{abstract}

Kata Kunci: Survey, Question, Read, Recite, Review (SQ3R), membaca pemahaman, Meta analisis

\section{PENDAHULUAN}

Membaca merupakan bagian yang terpenting di kehidupan ini, dalam berbagai aktivitas yang dilakukan hampir semua membutuhkan kegiatan membaca. Seperti halnya untuk membaca pesan, mengetahui waktu, membaca berita, dan aktivitas membaca lainnya. Apalagi pada masa perkembangan IPTEK 4.0 yang berkembang sekarang ini, dapat dirasakan bahwa kegiatan membaca tidak bisa lepas dari rutinitas kehidupan manusia. Hampir setiap hari menerima dan mengirim informasi melalui media elektronik dan media cetak. Maka dari itu, dibutuhkan pemahaman untuk membaca. Kebutuhan membaca menjadi hal yang penting dalam aktivitas sehari-hari seperti halnya makan dan minum. Kemampuan membaca bisa didapatkan melalui pendidikan formal yaitu sekolah ataupun pendidikan nonformal seperti kursus (Suratno, 2014).

Iskandarwassid dan Dadang Sunendar mengatakan bahwa kemampuan membaca pada umumnya diperoleh dengan mempelajarinya di sekolah. Pada jenjang pendidikan dasar, guru sekolah dasar memegang peranan yang sangat 
penting dalam membimbing dan mengarahkan para siswa agar mereka mampu menguasai berbagai kegiatan dalam proses membaca pemahaman, karena siswa yang kurang cakap membaca akan mengalami kesulitan dalam menguasai serta mempelajari ilmu-ilmu lain (Dyahpuspita, 2015).

Menurut Dalman membaca merupakan proses kognitif atau proses mencari dan menemukan informasi yang terdapat dalam sebuah tulisan. Membaca bukan hanya sekedar mengerti kumpulan huruf, kata dan kalimat dalam paragraf saja, tetapi membaca adalah proses memahami sebuah pesan dan maksud yang disampaikan penulis dalam tulisan tersebut, sehingga pesan tersebut dapat diterima oleh sang pembaca (Meliyawati, 2016).

Sekolah Dasar merupakan pendidikan mendasar belajar 6 tahun yang dituntut agar dapat memberikan ilmu yang bermanfaat bagi siswa. Guru sebagai tenaga pendidik mempunyai andil yang besar dalam pemerolehan keterampilan belajar, yang mana setiap anak memiliki bakat dan kemampuan yang berbedabeda, sehingga guru juga harus memperlakukan siswa sesuai dengan bakat dan kemapuannya masing-masing.

Sesuai dengan Permendikbud RI No 23 tahun 2015 tentang Budi pekerti menyebutkan bahwa:

Setiap siswa mempunyai potensi berbedabeda. Sekolah hendaknya melayani secara optimal agar siswa bisa menemukenali dan mengembangkan potensinya. Menggunakan lima belas menit sebelum hari pembelajaran untuk membaca buku selain buku mata pelajaran (setiap hari) (Mendikbud, 2015).

Plt. Direktur Jenderal Guru dan Tenaga Kependidikan Hamid Muhammad mengatakan dalam kompas.com bahwa tahun 2018 merupakan tahun terakhir pelatihan dan pendampingan kurtilas. Mulai tahun 2018 Kurikulum 2013 harus digunakan oleh semua sekolah tanpa kecuali. Tujuan pendampingan itu untuk memperkuat pemahaman mengenai Kurikulum 2013 dan juga perubahannya yang ada di lapangan, serta mampu mengatasi berbagai persoalan yang menjadi kendala dalam pelaksanan kurikulum di sekolah. Para pendamping diharapkan dapat mencermati dengan mendalam terkait apa saja yang terjadi di kelas (Kompas, 2018).

Target dari implementasi Kurikulum 2013 yang pertama adalah perubahan pendidikan karakter yang terintegrasi di sekolah, baik intrakurikuler, ekstrakurikuler, maupun kokurikuler. Kemudian pemerintah menargetkan terjadi perubahan budaya literasi di sekolah. Misalnya, guru dapat menargetkan siswanya untuk menuntaskan 4 hingga 5 buku bacaan per tahun. Anak-anak jangan cuma disuruh untuk menghafal. HOTS (Higher Order Thinking Skills) itu bukan hanya milik anak SMA saja. Tetapi sejak dini harus diperkenalkan kepada siswa kita. Sasaran terakhir, sekolah harus mampu memperkenalkan dan melatih keterampilan abad ke-21 ke siswa. Siswa harus dilatih untuk berpikir kritis, kreatif, komunikatif, dan mampu berkolaborasi.

Sekretaris Direktorat Jenderal Guru dan Tenaga Kependidikan E. Nurzaman juga menjelaskan bahwa guru berperan sebagai fasilitator di dalam menerapkan Kurikulum 2013. Menurut dia, pemerintah mengintegrasikan antara Kurikulum 2013 dengan dua program besar pemerintah lainnya yaitu Penguatan Pendidikan Karakter (PPK) dan Gerakan Literasi Sekolah (GLS). "Dengan integrasi pelatihan Kurikulum 2013 dengan PPK dan GLS akan meningkatkan kompetensi guru dan lebih mengefisienkan anggaran negara terkait pelatihan untuk guru (Kurniasih, 2018).

Disekolah dasar, membaca pada kelas rendah dan kelas tinggi memiliki tujuan yang berbeda. Pembelajaran membaca dikelas rendah bertujuan untuk mengenalkan huruf, kata dan kalimat sederhana pada anak. Sistem pembelajaranya dikenal dengan istilah membaca 
awal (membaca permulaan). Sedangkan pada kelas tinggi bertujuan agar anak memahami apa yang dibaca (membaca pemahaman) (Sintawati, 2016).

Pemahaman bacaan merupakan komponen penting dalam suatu aktivitas membaca, sebab pada hakikatnya pemahaman atas bacaan dapat meningkatkan keterampilan atau kepentingan membaca itu sendiri maupun untuk tujuantujuan tertentu yang telah ditentukan atau hendak dicapai. Palawija mengemukakan bahwa “...pemahaman merupakan kemampuan untuk membaca dan memahami tulisan". Dengan demikian, jika pembaca bisa berhasil mengambil makna dari bacaan yang telah dibaca, maka proses membaca pemahaman bisa dikatakan berhasil. Begitu pula sebaliknya, apabila seseorang tidak bisa mengambil makna dari bacaan yang dibaca, maka proses tersebut belum dikatakan berhasil (Farida, 2007).

Membaca seharusnya memiliki tujuan, sebab dengan mempunyai tujuan, seseorang akan lebih mudah memahami suatu bacaan dibanding yang tidak memiliki tujuan (Farida, 2007). Hal ini sependapat dengan Anne Ediger, Robertta Alexander, dan Krystyna Srutwa bahwa untuk memahami sebuah bacaan setiap orang mempunyai asumsi dan tujuan membaca yang berbeda-beda. Oleh karena itu, dalam pembelajaran membaca di kelas, seyogyanya guru menyusun tujuan membaca, atau dengan membantu siswa menyusun tujuan membacanya sendiri. Pendapat Sim, B. Laufer, dan Dvorkin berkaitan dengan tujuan membaca dapat didiskripsikan yaitu untuk: (1) membedakan materi yang penting dengan materi yang tidak penting, (2) membedakan antara informasi yang relevan dengan informasi yang tidak relevan, (3) mendukung suatu pernyataan maupun menolak pernyataan, mendapatkan ide berdasarkan penjelasan dan contoh, (5) mengenali implikasi, (6) memahami hubungan antarkalimat, (7) menyamakan argumen, dan (8) membuat prediksi (Khuzaimatun, 2009). Apabila dianalisis tujuan membaca Sim, dkk. di atas sejalan dengan pendapat Greane dan Patty sebagaimana dikutip oleh Tarigan bahwa tujuan membaca pemahaman diantaranya: (1) menemukan ide pokok kalimat, paragraf, wacana, (2) memilih butir-butir penting, (3) menentukan organisasi bacaan,(4) menarik kesimpulan, (5) menduga makna dan meramalkan dampak-dampak, (6) merangkum kejadian-kejadian, (7) membedakan fakta dan opini, dan (8) memperoleh informasi dari berbagai sumber seperti kamus bahasa indonesia ensiklopedi, atlas,internet dan lain sebagainya (Jainiyah, 2015).

Selain tujuan membaca pemahaman yang disampaikan oleh beberapa ahli diatas, secara umum membaca pemahaman juga sangat berhubungan dengan hasil belajar siswa. Pendapat ini dikuatkan oleh hasil penelitian (Diana, 2020) yang menyatakan terdapat hubungan antara kemampuan membaca pemahaman buku teks dan keterampilan berpikir kritis dengan hasil belajar pendidikan agama Islam, sebesar $67 \%$. Simpulan penelitian ini adalah peningkatan hasil belajar pendidikan agama Islam dapat dilakukan melalui peningkatan kemampuan membaca pemahaman buku teks dan keterampilan berpikir kritis siswa. Asumsi dari hasil penelitian ini adalah membaca pemahaman berpengaruh terhadap hasil belajar siswa pada seluruh mata pelajaran.

Kenyataan diatas diperlukan adanya suatu alternatif pemecahan masalah yang tepat. Karena membaca bukanlah pelajaran yang mudah dipahami. Banyak faktor pendukung keberhasilan anak dalam membaca seperti guru, siswa, kondisi lingkungan, materi pelajaran, serta metode dalam mempelajari materi pelajaran. Faktor terakhir yang dapat mempengaruhi keberhasilan siswa dalam membaca adalah penguasaan teknik-teknik 
membaca. Ada banyak metode membaca yang dapat diterapkan untuk dapat mencapai prestasi membaca yang baik. Adapun salah satu metode yang dapat digunakan dalam pembelajaran membaca pemahaman adalah metode SQ3R.

SQ3R merupakan singkatan dari Survey, Question, Read, Recite, Review. Model pembelajaran SQ3R dilaksanakan dengan tahapan-tahapan tertentu yakni pertama, menyurvei bacaan (survey), ke-dua menyusun daftar pertanyaan dari bacaan (question), ke-tiga membaca bacaan (read), ke-empat, menjelaskan bacaan (recite) ke-lima, meninjau ulang teks pertanyaan dan jawaban (review).

Model pembelajaran SQ3R menurut Syah pada prinsipnya merupakan langkah prosedural untuk mempelajari dan memahami isi teks dalam buku, artikel dan sebagainya. Metode SQ3R dikembangkan oleh Prof. Francis $\mathrm{P}$ Robinson, seorang guru besar psikologi dari Ohio State University sejak tahun 1941. Nurhadi dalam memberi istilah syrtabaku (survey, tanya, baca, katakana, ulang). Metode ini dirancang menurut jenjang yang memungkinkan siswa untuk belajar sistematis dan efisien sehingga metode SQ3R lebih tepat digunakan untuk keperluan studi (Wijiasih, 2013).

Model pembelajaran SQ3R dalam penelitian ini adalah metode membaca yang terdiri dari lima langkah, yaitu dan survey, question, read, recite, dan review. Langkah pembelajaran membaca pemahaman yang dilakukan adalah sebagai berikut.

a. Tahap survey, siswa membaca secara sekilas teks bacaan yang telah diperoleh.

b. Tahap question, siswa membuat pertanyaan berdasarkan bacaan.

c. Tahap read, siswa membaca secara keseluruhan teks bacaan.

d. Tahap recite, siswa menjawab pertanyaan yang telah dibuat pada tahap question, mencatat hal penting, dan meringkas atau menceritakan kembali teks bacaan yang telah dibaca.

e. Tahap review, siswa meninjau ulang teks bacaan, membaca ulang intisari yang telah didapatkan dan dibuat serta bila diperlukan dapat pula membaca kembali bahan bacaan.

Berdasarkan uraian permasalahanpermasalahan tersebut, maka peneliti ingin menganalisis hasil penelitian yang relevan dari berbagai sumber dengan tujuan untuk menganalisis penggunaan model pembelajaran survey, question, read, recite, dan review (SQ3R) guna meningkatkan pemahaman membaca siswa jenjang Sekolah Dasar. Sehingga dapat dirumuskan masalah, apakah penggunaan metode pembelajaran SQ3R (survey, question, read, recite, review) dapat meningkatkan keterampilan membaca pemahaman siswa Sekolah Dasar?

\section{METODE}

Penelitian dilaksanakan dengan pendekatan kualitatif dengan metode MetaAnalisis. Metode Meta-Analisis merupakan metode penelitian yang dilakuakan dengan cara merangkum, mereview, dan menganalisis data penelitian dari beberapa hasil penelitian sebelumnya (Noor, 2014). Pengumpulan data dalam penelitian ini dengan cara mencari jurnal dan skripsi yang relevan dari media elektronik sesuai dengan judul penelitian. Dari penelusuran di media elektronik diperoleh beberapa hasil jurnal dan skripsi yang relevan kemudian dipilih berdasarkan kriteria yaitu adanya data yang jelas sebelum diberikan tindakan (treatment) dan setelah diberikan tindakan (treatment) kemudian data yang diperoleh dianalisis. Analisis menggunakan metode pembanding dalam menentukan adanya peningkatan data selisih sebelum diberikan tindakan (treatment) dan setelah diberikan tindakan (treatment). Data yang diperoleh dihitung skor untuk mengetahui berapa (\%) peningkatan terhadap hasil belajar. 


\section{HASIL DAN PEMBAHASAN}

\section{Hasil Penelitian}

Hasil penelitian yang relevan disertakan dalam meta analisis adalah sebagai berikut.

1. Anggraeni Sintawati: Pengaruh metode Survey, Question, Read, Recite, Review (SQ3R) Terhadap Keterampilan Membaca Pemahaman Siswa Kelas IV SDN Gugus Jendral Sudirman.

2. Nurdia Artu: Upaya Meningkatkan Kemampuan Membaca Pemahaman Siswa Kelas IV SDN Pembina Liang Melalui Penerapan Strategi Survey Questions Reading Recite Review (SQ3R).

3. Widya Arta Pujana, Ni Wy. Arini, I G. Wawan Sudatha: Pengaruh Metode Pembelajaran SQ3R Terhadap Keterampilan Membaca Pemahaman Bahasa Indonesia Siswa Kelas IV.

4. Anis Finalisa: Peningkatan Keterampilan Membaca Pemahaman Melalui Penerapan Metode Survey, Question, Read, Recite, Review (SQ3R) Pada Siswa Kelas V MI Unwaanunnajah Pondok Aren Tahun Ajaran 2014/2015.

5. Dede Fadillah: Meningkatkan Keterampilan Membaca Pemahaman Dengan Menggunakan Metode Survey, Question, Read, Recite, Review (SQ3R) Pada Siswa Kelas V MIN 1 Pesawaran Tahun Ajaran 2016/2017.

6. Catur Agustina Candra Dewi: Penerapan Strategi SQ3R Untuk Meningkatkan Keterampilan Membaca Pemahaman Di Sekolah Dasar.

7. Aulia Rahmawati: Penerapan SQ3R Berbantunan Reka Cerita Gambar Untuk Meningkatkan Pemahaman Membaca Dan Hasil Belajar Siswa.

8. Wawan Krismanto, Abdul Khalik, Sayidiman: Meningkatkan
Kemampuan Membaca Pemahaman Melalui Metode Survey, Question, Read, Recite, Review (SQ3R) Pada Siswa Kelas IV SD Negeri 46 Parepare.

9. Anggun Dwi Setya P, Rukayah, Yulianti: Penggunaan Metode Pembelajaran Survey, Question, Read, Recite, Review (SQ3R) Untuk Meningkatkan Keterampilan Membaca Pemahaman Dalam Mata Pelajaran Bahasa Indonesia.

10. Wening Nadzifah: Upaya Meningkatkan Keterampilan Membaca Pemahaman Menggunakan Metode SQ3R Siswa Kelas IV SDN Katongan I Nglipar Gunungkidul Tahun Ajaran 2015/2016.

Berdasarkan data hasil penelitian terdahulu yang relevan, maka peneliti menelaah kembali hasil penelitian sebelumnya yang ada kemudian menganalisis hasil penelitian tersebut untuk mengetahui hasil akhir dari setiap penelitian. Selanjutnya data dianalisis secara deskriptif kuantitatif dan kualitatif. Berikut adalah hasil analisis yang disajikan dari 10 hasil penelitain terdahulu.

Tabel 1 Hasil Analisis Survey, Question, Read, Recite, Review (SQ3R) terhadap membaca pemahaman Kuantitatif

\begin{tabular}{|c|c|c|}
\hline No & Peneliti & $\begin{array}{c}\text { Hasil Penelitian } \\
\text { Membaca Pemahaman }\end{array}$ \\
\hline \multirow{6}{*}{1} & \multirow{6}{*}{$\begin{array}{l}\text { Anggraeni } \\
\text { Sintawati }\end{array}$} & $\begin{array}{ll}\text { Penerapan } & \text { model } \\
\text { pembelajaran } & \text { SQ3R }\end{array}$ \\
\hline & & $\begin{array}{lr}\text { terhadap } & \text { keterampilan } \\
\text { membaca } & \text { pemahaman } \\
\text { lebih } & \text { tinggi } \\
\text { dibandingkan } & \text { dengan }\end{array}$ \\
\hline & & model ceramah bagi \\
\hline & & siswa kelas IV SD \\
\hline & & Negeri Gugus Jendral \\
\hline & & $\begin{array}{l}\text { Sudirman.dibuktikan } \\
\text { dari hasil t-test tersebut }\end{array}$ \\
\hline
\end{tabular}




\begin{tabular}{cl}
\hline & dengan taraf signifikansi \\
& $5 \%$ (derajat kepercayaan \\
& $95 \%$ diperoleh t hitung \\
& $(2,212)>$ t tabel $(2,039)$. \\
& (Sintawati, 2016). \\
\hline & Terdapat perbandingan \\
& yang signifikan antara \\
Widya & penerapan metode \\
Arta & pembelajaran SQ3R \\
Pujana, & dengan penerapan model \\
Ni Wy. & pembelajaran \\
Arini, I G. & konvensional \\
Wawan & pembelajaran bahasa \\
Sudatha & Indonesia dengan hasil $(\mathrm{t}$ \\
& hitung =6,29; $<0,05)$ \\
& (Pujana, 2014).
\end{tabular}

Tabel 2 Hasil Analisis Survey, Question, Read, Recite, Review (SQ3R) terhadap membaca pemahaman Kualitatif

\begin{tabular}{cl}
\hline No Peneliti & \multicolumn{2}{c}{ Hasil Penelitian } \\
& Membaca Pemahaman \\
\hline & Pada siklus I berada \\
& pada kategori kurang, \\
& siklus II berada pada \\
& kategori cukup dan \\
& siklus III mengalami \\
Nurdia & peningkatan dan berada \\
Artu & pada kategori sangat \\
& baik. Hal ini dapat \\
& dilihat dari hasil tes \\
& setiap proses \\
& pembelajaran \\
& menunjukkan pada \\
\hline siklus I nilai rata-rata \\
kelas mencapai 66,13 \\
dengan ketuntasan \\
belajar mencapai 50\%, \\
siklus II nilai rata-rata \\
kelas mencapai 72,27 \\
dengan ketuntasan \\
belajar \\
mencapai 63,63\%, dan \\
siklus III nilai rata-rata \\
\hline
\end{tabular}

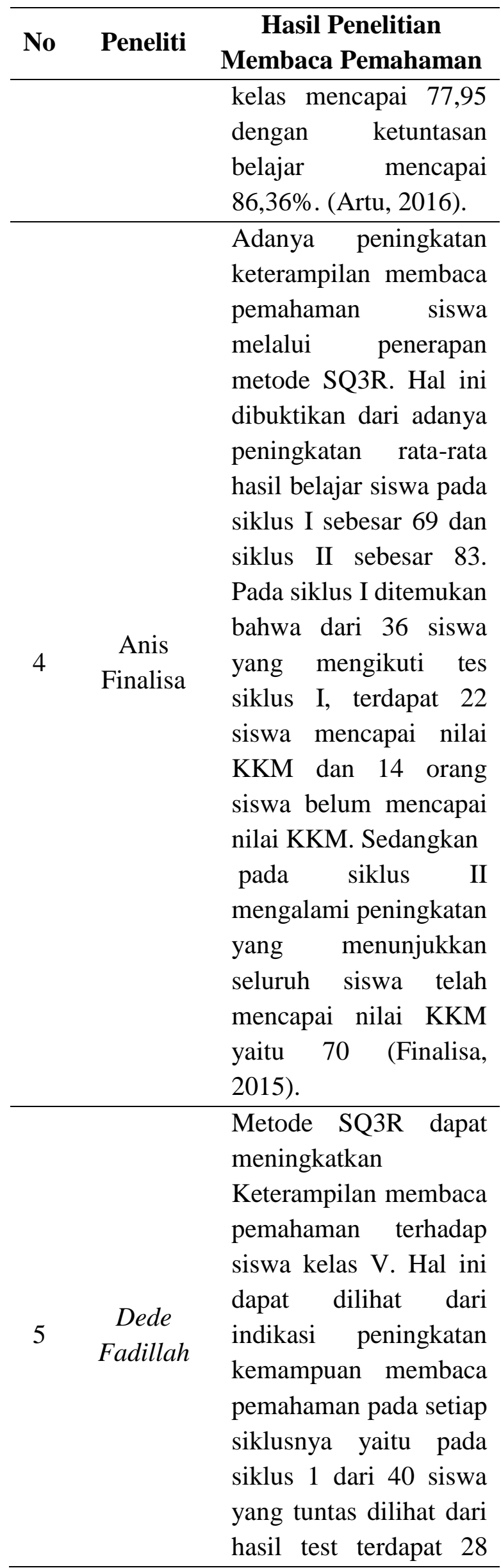




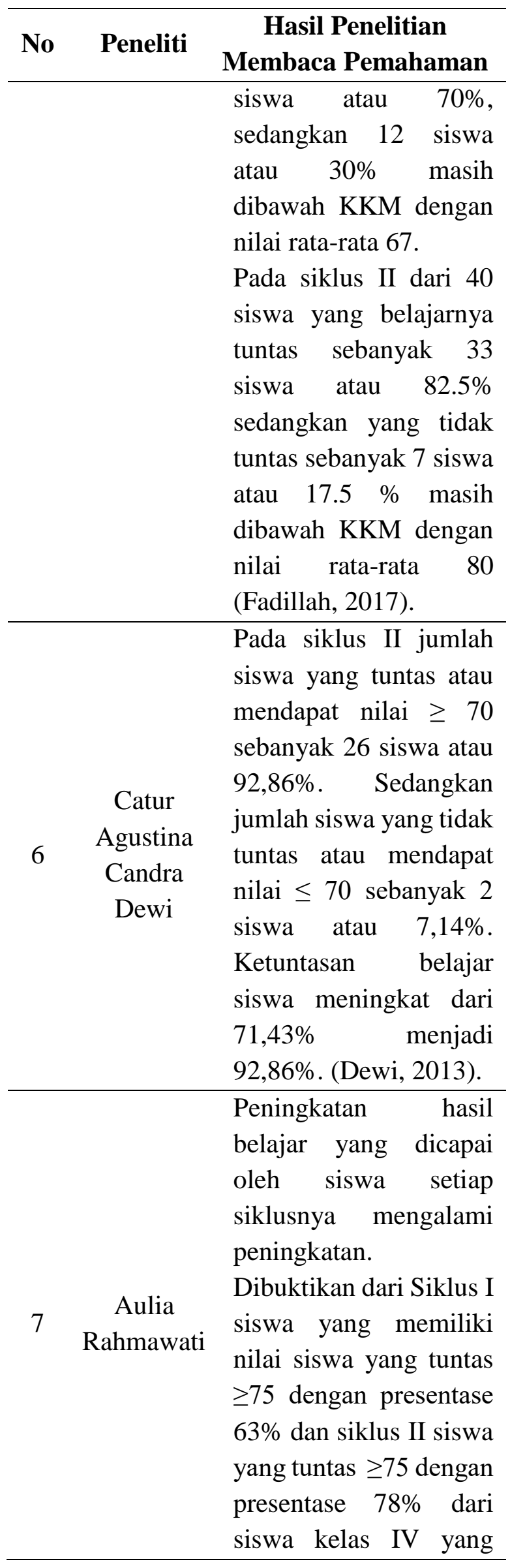

\begin{tabular}{|c|c|c|}
\hline No & Peneliti & $\begin{array}{c}\text { Hasil Penelitian } \\
\text { Membaca Pemahaman }\end{array}$ \\
\hline & & $\begin{array}{l}\text { berjumlah } 27 \text { siswa } \\
\text { (Rahmawati, 2016). }\end{array}$ \\
\hline 8 & $\begin{array}{l}\text { Wawan } \\
\text { Krismanto, } \\
\text { Abdul } \\
\text { Khalik, } \\
\text { Sayidiman }\end{array}$ & $\begin{array}{l}\text { Metode SQ3R dapat } \\
\text { meningkatkan } \\
\text { Keterampilan membaca } \\
\text { pemahaman terhadap } \\
\text { siswa kelas IV SD N } 46 \\
\text { Parepare. Dengan } \\
\text { melihat hasil di siklus } \\
\text { III hasil belajar siswa } \\
\text { dapat maksimal sesuai } \\
\text { harapan dimana 84,21\% } \\
\text { siswa dapat tuntas } \\
\text { dalam pembelajaran } \\
\text { membaca pemahaman } \\
\text { di kelas IV SD N } 46 \\
\text { Parepare semester } \\
\text { ganjil (Krismanto, } \\
\text { 2015). }\end{array}$ \\
\hline 9 & $\begin{array}{c}\text { Anggun } \\
\text { Dwi Setya } \\
\text { P, } \\
\text { Rukayah, } \\
\text { Yulianti }\end{array}$ & 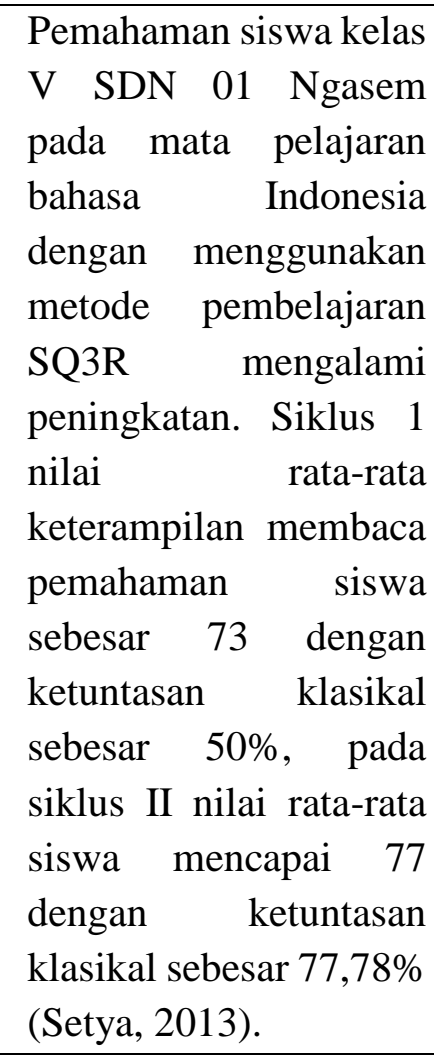 \\
\hline 10 & $\begin{array}{l}\text { Wening } \\
\text { Nadzifah }\end{array}$ & $\begin{array}{l}\text { Peningkatan siswa } \\
\text { kelas IV SDN Katongan } \\
\text { I proses pembelajaran } \\
\text { ditunjukkan dengan }\end{array}$ \\
\hline
\end{tabular}




\begin{tabular}{ll}
\hline No Peneliti & $\begin{array}{c}\text { Hasil Penelitian } \\
\text { Membaca Pemahaman }\end{array}$ \\
\hline & siswa lebih aktif dan \\
& antusias mengikuti \\
& proses pembelajaran \\
& menggunakan metode \\
& SQ3R. Sedangkan \\
& peningkatan hasil \\
& pembelajaran rata-rata \\
& hasil tes membaca \\
& pemahaman mencapai \\
& $61,11 \quad$ dengan \\
& perhitungan pada pada \\
& siklus I mencapai rata- \\
& rata 68,53 dan siklus II \\
& mencapai nilai rata-rata \\
& $77,58$. Sehingga jika \\
& diprosentasikan nilai \\
& mencapai 70 pada pra- \\
& tindakan mendapat \\
hasil 16,67\%, pada & siklus I mendapat hasil \\
& $61,11 \%$ dan pada siklus \\
& II mendapat hasil 100\% \\
& (Nadzifah, 2016).
\end{tabular}

\section{Sumber: Olahan peneliti}

\section{Pembahasan}

Berdasarkan tabel di atas, disajikan dua jenis penelitian yang menggunakan variabel SQ3R dan kemampuan membaca pemahaman dalam pembelajaran Bahasa Indonesia yaitu 8 Penelitian Tindakan Kelas (PTK) dan 2 penelitian kuantitatif (eksperimen). Pada Penelitian Tindakan Kelas (PTK) diperoleh hasil rata-rata ketuntasan hasil belajar sebesar 87,71 $\%$. Sedangkan pada penelitian kuantitatif (eksperimen) didapatkan hasil bahwa SQ3R berpengaruh terhadap membaca pemahaman siswa dibuktikan dengan hasil uji $t$ kedua penelitian dengan skor $t^{1}=2,212, t^{2}=6,29$ dengan diperoleh rata-rata 4,251 sehingga disimpulkan bahwa nilai t hitung $>\mathrm{t}$ tabel.

Berdasarkan penelitian yang relevan yang telah dianalisis, terlihat hasil tiap penelitian memperoleh peningkatan yang berbeda-beda. Sejalan dengan pendapat Hamalik mengemukakan keberhasilan belajar dapat dipengaruhi oleh faktor dari dalam (internal) dan faktor dari luar (eksternal) yang mempengaruhi hasil belajar. Penggunaan model pembelajaran SQ3R yang diterapkan juga mempengaruhi peningkatan terhadap hasil belajar yang diperoleh siswa (Ramadhani, 2019).

Penulis menganalisis jika perbedaan dan peningkatan membaca pemahaman yang telah dilakukan para peneliti dikarenakan faktorfaktor yang mempengaruhi keberhasilan belajar dan penggunaan model Survey, Question, Read, Recite, Review (SQ3R) yang dipilih peneliti untuk melakukan penelitian tersebut. Kondisi tempat penelitian yang berbeda juga mempengaruhi hasil penelitian. Tingkat kemampuan yang dimiliki oleh siswa juga berbeda hal itu juga mempengaruhi hasil belajar. Kondisi jasmasni dan rohani siswa juga mempengaruhi hasil belajar yang diperoleh siswa. Penerapan model pembelajaran Survey, Question, Read, Recite, Review (SQ3R) pada saat kegiatan pembelajaran yang dilakukan pendidik juga mempengaruhi hasil belajar yang diperoleh siswa.

Penggunaan model pembelajaran SQ3R memberi kemungkinan kepada pembacanya untuk menentukan apakah materi yang dihadapinya itu sesuai dengan keperluannya atau tidak. SQ3R memberikan kesempatan kepada pembacanya untuk bersifat fleksibel. Siswa diarahkan untuk terbiasa berpikir terhadap bahan bacaan sehingga siswa menjadi lebih aktif dan terlatih untuk bisa membuat pertanyaan. Metode SQ3R mungkin tak banyak berbeda dengan mempelajari teks secara biasa. Akan tetapi, hasil pembelajaran siswa dengan menggunakan metode ini diharapkan mendapatkan hasil yang memuaskan, sebab dengan metode ini para siswa menjadi pembaca aktif dan terarah langsung pada kandungan pokok atau intisari yang tersirat dan tersurat dalam teks. Pembaca juga dibekali 
dengan metode yang sistematis, sehingga kemauan siswa dalam melaksanakan kegiatan pembelajaran meningkat, siswa lebih aktif dalam pelaksaanaan kegiatan pembelajaran, dan adanya interaksi antara pendidik dan siswa sehingga kegiatan pembelajaran akan terasa lebih bermakna dan hasil belajar yang diperoleh siswa meningkat.

\section{PENUTUP}

\section{Simpulan}

Hasil analisis penulis terhadap penerapan model pembelajaran Survey, Question, Read, Recite, Review (SQ3R) yang telah dilakukan oleh para peneliti dapat meningkatkan membaca pemahaman siswa. Perihal tersebut dapat dibuktikan dari hasil data yang diperoleh menunjukkan peningkatan pada Penelitian Tindakan Kelas (PTK) diperoleh hasil rata-rata ketuntasan ketrampilan membaca pemahaman sebesar 87, $71 \%$. Sedangkan pada penelitian kuantitatif (eksperimen) didapatkan hasil bahwa SQ3R berpengaruh terhadap membaca pemahaman siswa dibuktikan dengan hasil uji $\mathrm{t}$ kedua penelitian dengan skor $\mathrm{t}^{1}=2,212, \mathrm{t}^{2}=6,29$ dengan diperoleh rata-rata 4,251 sehingga disimpulkan bahwa nilai $\mathrm{t}$ hitung $>\mathrm{t}$ tabel. Hasil tersebut menunjukkan bahwa pembelajaran keterampilan membaca pemahaman menggunakan metode SQ3R telah memenuhi indikator keberhasilan proses dan produk dalam penelitian ini. Sehingga penelitian ini dapat dikatakan berhasil.

Faktor internal dan eksternal juga mempengaruhi hasil belajar yang diperoleh siswa karena dengan menggunakan model tersebut pendidik dan siswa dapat berinteraksi serta dapat membangun pemahaman membaca dengan mudah yang berimplikasi pada peningkatan hasil belajar.

\section{Saran}

Berdasarkan hasil analisis model pembelajaran SQ3R dalam meningkatkan membaca pemahaman siswa SD saran yang dapat diberikan adalah:

\section{Bagi Siswa}

Siswa dapat mempraktekkan metode SQ3R untuk kegiatan membaca. Siswa harus aktif dan memperhatikan pembelajaran, sehingga dapat memahami materi pembelajaran yang disampaikan. Kebiasaan serta kegemaran membaca perlu ditingkatkan agar lebih terlatih membaca sehingga lebih mudah memahami bacaan.

\section{Bagi Guru}

Guru harus menciptakan pembelajaran yang efektif dan menyenangkan yang membuat siswa aktif dan antusias mengikuti pembelajaran, serta membantu siswa untuk memahami materi pembelajaran. Dalam pembelajaran membaca pemahaman guru hendaknya mengajarkan siswa tentang strategi, metode, dan teknik membaca yang baik sehingga siswa mamahami isi bacaan dengan baik dan mudah. Metode SQ3R dapat digunakan sebagai salah satu metode pemelajaran, khusunya pembelajaran membaca pemahaman. Metode SQ3R juga dapat digunakan untuk mata pelajaran lain.

\section{Bagi Sekolah}

Sekolah hendaknya melengkapi fasilitas, sarana dan prasarana yang dibutuhkan guru dan siswa sehingga dapat meningkatkan kualitas pembelajaran.

\section{Bagi Peneliti Lain}

Sebaiknya mengadakan penelitian yang lebih lanjut terhadap faktor-faktor yang menyebabkan rendahnya membaca pemahaman siswa dengan menggunakan metode-metode pembelajaran yang lebih inovatif.

\section{DAFTAR PUSTAKA Dari Buku}

Anitah, S. 2009. Strategi Pembelajaran di SD. Jakarta: Universitas Terbuka.

Djamarah, S. B. 2010. Guru dan Anak Didik dalam Interaksi Edukatif. Jakarta: Rineka Cipta. 
Farida, R. 2007. Pengajaran Membaca di Sekolah Dasar. Jakarta: Bumi Aksara.

Kemendikbud. 2013. Kompetensi Dasar Sekolah Dasar (SD)/Madrasah Ibtidaiyah. Jakarta: Kemendikbud.

Meliyawati. 2016. Pemahaman membaca dasar. Yogyakarta: Deepublish.

Noor, J. 2014. Metodologi Penelitian : Skripsi, tesis, desertasi, Karya ilmiah. Malang: Kencana Prenada Media group.

Sudrajat, A. 2008. Pengertian Pendekatan, Strategi, Metode, Teknik dan Model Pembelajaran. Bandung: Sinar Baru Algensindo.

\section{Dari Jurnal}

Artu, N. 2016. Upaya Meningkatkan Kemampuan Membaca Pemahaman Siswa Kelas IV SDN Pembina Liang Melalui Penerapan Strategi Survey Questions Reading Recite Review (SQ3R). Jurnal Kreatif Tadulako Online Vol. 2 No. 2.

Dewi, C. A. 2013. Penerapan strategi SQ3R untuk meningkatkan ketrampilan membaca pemahaman di sekolah dasar. JPGSD Volume 01 Nomor 02 .

Jainiyah, S. 2015. Penerapan strategi direct reading thinking activity (DRTA) untuk meningkatkan keterampilan membaca pemahaman tema berbagai pekerjaan siswa kelas sekolah dasar. JPGSD. Volume 03 Nomor 01

Krismanto Wawan, A. K. 2015. Meningkatkan kemampuan membaca pemahaman melalui Survey, question, Read, Recite, Review (SQ3R) pada siswa kelas IV SD Negeri 46 Pare-pare. Publikasi Pendidikan.

Pujana Widya Arta, N. W. 2014. Pengaruh Pembelajaran SQ3R Terhadapp ketrampilan membaca pemahaman Bahasa Indonesia siswa kelas IV. Mimbar PGSD Universitas Pendidikan Ganesha.
Rahmawati, A. 2016. Penerapan SQ3R Berbantunan Reka cerita gambar untuk meningkatkan pemahaman membaca dan hasil belajar siswa. Profesi Pendidikan Dasar.

Setya Anggun Dwi, R. Y. 2013. Pengguanaan metode pembelajaran survey, question, Read, Recite, Review (SQ3R) untuk meningkatkan ketrampilan membaca pemahaman dalam mata pelajaran Bahasa Indonesia. Kalam Cendekia.

\section{Dari Skripsi}

Diana, F. 2020. kemampuan membaca pemahaman buku Teks dan ketrampilan berpikir kritis dengan hasil belajar pendidikan agama Islam (Penelitian di SMP Negeri 2 Cimanuk kabupaten pandeglang). Banten: UIN SMH Banten. Dyahpuspita, N. 2015. Pengaruh Metode SQ3R Terhadap Kemempuan membaca pemahaman siswa kelas IV.2 SD Muhammadiyah Mutihan Tahun Pelajaran 2014/2015. 1.

Fadillah, D. 2017. Meningkatkan ketrampilan membaca pemahaman melalui penerapan metode survey, Question, Read, Recite, Review (SQ3R) pada siswa kelas V MI Unwaanunnajah pondok aren tahun pelajaran 2016/2017. Lampung: IAIN Raden Intan Lampung.

Finalisa, A. 2015. Peningkatan Keterampilan Membaca Pemahaman Melalui Penerapan Metode Survey, Question, Read, Recite, Review (SQ3R) Pada Siswa Kelas V MI Unwaanunnajah Pondok Aren Tahun Ajaran 2014/2015. Jakarta: UIN Syarif Hidayatullah.

Khuzaimatun, S. 2009. Upaya meningkatkan kemampuan membaca pemahaman dengan metode SQ3R pada siswa kelas X.3 SMA Negeri 1 Sumberlawang. Surakarta: Universitas Sebelas Maret Surakarta. 
Nadzifah, W. 2016. Upaya Meningkatkan Ketrampilan Membaca Pemahaman Menggunakan Metode SQ3R Siswa Kelas IV SDN Katongan I Nglipar GunungKidul Tahun Ajaran 2015/2016. Yogyakarta: Universitas Negeri Yogyakarta.

Ramadhani, D. 2019. Pengaruh Model Pembelajaran Realistic Mathematics Education (RME) Terhadap Hasil Belajar Matematika Siswa Kelas V Min 7 Medan Denai T.A 2018/2019. Medan: Universitas Islam Negeri. Skripsi S1.

Rifa'i, A. 2012. Psikologi Pendidikan. Semarang: pusat pengembangan MKU/MKDK-LP3 Universitas Negeri Semarang.

Sintawati, A. 2016. Pengaruh Metode Sq3r (Survey, Question, Read,Recite, Review)Terhadap Keterampilan Membaca Pemahaman Siswa Kelas Iv Sdn Gugus Jendral Sudirman. semarang: Universitas Negeri Semarang.

Solchan T. W, d. 2010. Pendidikan Bahasa Indonesia di SD. Jakarta: Universitas terbuka.

Suratno, A. 2014. Peningkatan kemampuan membaca pemahaman menggunakan teknik scrumble wacan siswa kelas IV A SDN Tukangan Yogyakarta. Skripsi, 1.

Wijiasih, S. R. 2013. Peningkatan kemampuan membaca pemahaman wacana karangan eksposisi berbahasa jawa dengan metode SQ3R (survey, question, read, recite, review) pada siswa kelas viii e smp n 3 bobotsari. Yogyakarta: Universitas Negeri Yogyakarta.

\section{Dari Internet}

Kompas. 2018. Tahun ajaran baru sekolah wajib terapkan kurikulum 2013. https://edukasi.kompas.com diakses pada 21 Februari 2018.

Kurniasih, B. 2018. Kompas. Tahun ajaran Baru Sekolah Wajib terapkan kurikulum 2013, hal. 1. https://edukasi.kompas.com diakses pada 25 Februari 2018.

\section{Dari Permen}

Mendikbud. 2015. Peraturan Menteri Pendidikan dan kebudayaan RI No 23 Tahun 2015. Jakarta: Tidak diterbitkan. 